\title{
CORRIGENDUM
}

\section{The serotonin transporter gene is a substrate for age and stress dependent epigenetic regulation in rhesus macaque brain: Potential roles in genetic selection and Gene $\times$ Environment interactions-CORRIGENDUM}

\author{
STEPHEN G. LINDELL, ${ }^{a}$ QIAOPING YUAN, ${ }^{a}$ ZHIFENG ZHOU, ${ }^{a}$ DAVID GOLDMAN, ${ }^{a}$ \\ ROBERT C. THOMPSON, ${ }^{b}$ JUAN F. LOPEZ, ${ }^{b}$ STEPHEN J. SUOMI, ${ }^{c}$ J. DEE HIGLEY, ${ }^{d}$ AND \\ CHRISTINA S. BARR ${ }^{a}$ \\ ${ }^{a}$ NIH/NIAAA $;{ }^{b}$ University of Michigan; ${ }^{c}$ NIH/NICHD; and ${ }^{d}$ Brigham Young University \\ doi:10.1017/S0954579412000788, published by Cambridge University Press, 15 October 2012
}

An important acknowledgment was not included in the original article. We gratefully acknowledge the support from a NARSAD Young Investigator Award (2004). We regret this oversight and any problems it may have caused. The first

\section{Reference}

Lindell, S., Yuan, Q., Zhou, Z., Goldman, D., Thompson, R. C., Lopez, J. F., et al. (2012). The serotonin transporter gene is a substrate for age and stress dependent epigenetic regulation in rhesus macaque brain: Potential two affiliations in the original article were the same, so they are also corrected herein. We regret this repetition and any problems it may have caused.

roles in genetic selection and Gene $\times$ Environment interactions. Development and Psychopathology, 24, 1391-1400. 